The Black Aesthetic in Rita Dove's Sonata Mulattica

$$
\begin{aligned}
& \text { Dr. Sally Michael Hanna } \\
& \text { Associate Professor - English Dep } \\
& \text { Vice Dean- Faculty of Education October } 6 \text { University } \\
& \text { د.سالى حنا ميخائيل } \\
& \text { أستاذ مساعد بقسم اللغة الإنجليزية } \\
& \text { وكيل كلية التربية لنشئون التعليم و الطلاب ـ جامعة ج اكتوبر الانسئ }
\end{aligned}
$$





\section{The Black Aesthetic in Rita Dove's Sonata Mulattica}

To Rita Dove, a renowned poet of great transformations and eclectic artistry, blackness is an aesthetic that needs to be embraced and celebrated. Dove's sense of integrationism invited Houston A. Baker's commentary on the broad range and richness of black representation in her work: "If black is the combined richness of all color, then Rita Dove is the singing blackness of blackness" $(1990,577)$. It is the project of this paper to reflect on blackness depicted in Rita Dove's Sonata Mulattica, a breakthrough volume that figures a reimaging of a black aesthetic that is universalized through music of transcendence presenting an "Ars Poetica" an "X marks the spot" leading to Dove's signature crossing. The volume sublimates race into a level of refinement that does modern blackness proud. So intensely woven, Sonata Mulattica features enormous lexical range and orchestral potential that verge on the reaches of poetic and narrative prophecy. Dove anchors the volume in artistry that lends itself to epiphanic moments that help one come to terms with personal tragedy. Having a purposeful design, the volume breaks fresh ground in the representation of blackness as it engages the reference with the historical. Aptly titled, Sonata Mulattica toys with musical motifs of motion and stasis that condition a return to a historical sweep of incidents that were willfully approximated if not eradicated from the history of world music. Before further elaboration on the volume and on Dove's black aesthetic particularly, I would like to reflect on the nature of Black discourse from the perspectives of Henry Louis Gates and Houston A. Baker, the great tycoons of black literary criticism in order to situate Dove vis a vis the representation of blackness and the racialization/ or deracialization of art. Focusing on their points of agreement helps serve the purposes of this research in advancing a progressive vision of a black aesthetic.

The black literary cannon was and always will be a point of great contention among scholars and writers alike because it is viewed as a right of passage to the road that not only defines the literary product of an era but also brackets the consciousness of a group by whom and about whom literature is written. Intent on defining the black canon, African Americanists express divergent perspectives on what constitutes black art. To some, blackness is a problematic to be confronted in order to walk a 
comfortable margin between the imperatives of political and cultural agency on the one hand and the reconstitution of black subjectivity on the other. A cacophony of expert voices morph their way around the problematic of the Black aesthetic in terms of its attendant metaphors of black distinction, black word, black structure, black consciousness, black saturation, black ethics and aesthetics, black power, liberation, integration etc. What emerges is a plethora of visions that expands the contours of Afro- American scholarship beyond its prescribed limits. The outcome of scholarly deliberations is the ascendancy of a paradigm that shifts at will to accommodate a rhetoric that bridges the yawning chasm between an entrenched arsenal of racial authority and the hegemony of western tradition. Such attempts at canon formation, too ambitious and discordant of scope, led at best to the clash of literary titans that papered the books of African American literary theory. Some such arguments have descended both literally and metaphorically into discordant polemic or personal wars in the strive to attain a vision of what Afro- American literature should be. A downside to such canon is the tendency toward turning texts into a marionette theatre of the political that upheld the stridency of the political message or seeking saturation in blackness out of social compulsion, which in itself is a privileging of a racial category that is in dire want of a definition. Such social dictates stylized art that is exclusionary of realities outside of blackness and is therefore abbreviated to the detriment of delivering the fullness of a writer's experience as it ignores the richness of the author's humanity. A new literature is to be willed into existence to tip the balance of black discourse. The literature in question approximates such paradox, allows entrance into a language acknowledging race without the venom or haunting pathos that embraces humanity at large.

Myriad issues that pertain to the importance of a return to history as a shaping power of African American consciousness and the preparation of a literary canon that influences Black life and culture rather than being influenced by it were among the queries that kept leading figures of the black literary canon occupied during the expanse of the twentieth century. There is no doubt that Black literature has teetered its way across a rough terrain moving across the Harlem Renaissance that baptized writing as art that proclaimed the beauty of black people to 
downright shameless polemic of the Black Arts Movement with its unapologetic bravado that ripped art off its beauty thus leaving it a deserted shrine of a sanctity defiled by militancy that only attracted aggression toward the cause. Taking power of representation back to a realm of art influenced by race but not interrupted by it helped in creating a black aesthetic of unity that sets firm roots in a Black vernacular that talked back to texts thus creating generational dialogue seeking empowerment embodied in the authenticity of images, words, and signs.

With regards to the formation of the black canon, Henry Louis Gates has posed a question that defines the query in his essay Canon Formation, Literary History and Afro-American Tradition: From the Seen to the Told: "is black poetry racial in theme, or is black poetry any sort of poetry written by black people? (32). In the context of the question, Gates attempts to gauge the level of 'social compulsion' of Black literature that Dubois contested earlier along with race as a sociopolitical category. What should black literature talk about and how does literature acquire its blackness? Gates formulates a unique vision of black literature in his Preface to Blackness: Text and Pretext:

Black literature is a verbal art like other verbal arts. Blackness is not a material object or an event or a metaphor; it does not have an essence as such but is defined by a network of relations that form a particular aesthetic unity. Even the slave narratives offer the text as a world, as a system of signs. The Black writer is the point of consciousness of his language. If he does embody a black aesthetic then it can be measured not by content but by a complex structure of meanings (162).

Gates promotes an aesthetic of a wholesomeness and comprehensiveness in content, context and sign. The consciousness of the author becomes the definitive guiding spirit of a work. The complex structure of meanings may refer to the power of the sign in establishing a proper base of signifying or talking back thus creating connections between texts. He refers mostly to "call and response," "echo," and he further stresses the vernacular roots of black language (1992 A, 38). 
Myriad attempts were made, Gates' is one of them, to free the canon from its subservience to white readers and the western tradition on the one hand and to liberate it from the excessive sense of enchainment that conditioned the extinction of all else that is not black, on the other, in the hope of conjuring up a "black text specific theory" (1992 A, 30). A relation between cognition and utterance is what Gates argues for as the main precept upon which a black rhetoric can be established, one that does not necessarily dwell on western theories as its only court of appeal because according to him dependence on another undermines "the passage from the seen to the told- from what we see to how we tell it- this basis for our own black public discourse, this relation between cognition and utterance" (1992 A, 30). In his later work, Gates has adopted a softer and more integrationist tone especially in his Notes on the Culture Wars published in Loose Cannons. Gates establishes a solid ground of interdependence between white and black texts as he acknowledges the influence of white texts on black texts and vice versa, he concludes that "a thoroughly integrated canon of American literature is not only politically sound, it is intellectually sound as well" (1992 B, 166). It is rightly argued that for literature to seek a form of authentication whether white or black, it has to reflect on life in its wholesome fullness which does not happen to represent blackness in isolation from whiteness. Furthermore, he bitterly criticizes Stephen Henderson's concept of black saturation i or what he refers to as "the wider context of the phenomenon which we call, for the sake of convenience, the Black Experience" (104) on the grounds of its warped and circular reasoning "poetry is black when it communicates blackness" (Gates 2000, 158).

Based on the argument that no one can opt out of history" (1992 B, 165), Gates attests to the importance of a return to history as a means to salvaging Blackness:

In our attempt at canon formation we are demanding a return to history in a manner scarcely conceived of by the new historicists. Nor can we opt of our own private histories, which Houston Baker calls the African American autobiographical moment, and which I call the autocritography (1992 B 166). 
The literature that Gates postulates is one that formulates a vision of blackness capable of self criticism and self betterment rather than being helplessly proscribed by what blackness means from a sociopolitical perspective; an argument that both Gates and Houston A. Baker postulated. In the wake of the Black power movement that attempted to utilize the concept of Blackness as an essence that brackets the literary product of Afro- Americans, Houston Baker celebrated "the emergent theoretical prospect" that "attempts to discover how the qualities of a literary domain shape Afro- American life as a whole. There is thus a move from the whole of culture to the part signaled by the most recent generational shift in Afro- American literary criticism" (2000 A, 198). Houston Baker thus endows more power into the literary canon as it emerges as a paradigm to be emulated not the other way around.

Moreover, Houston A. Baker argues for an African American canon that is "an expressive embodiment of spirit work" $(1992,136)$. A black national script of empowerment can come about by investing in the primacy of a black word of value $(2000 \mathrm{~B}, 128)$ and in the power of "imagistic fields" $(1992,150)$ that is a poetics that accesses "the general, overarching, or framing images and values of a culture as well as foregrounding the quite specific values or instances that modify or expand a general field" $(1992,150)$. Baker's poetics may as well be described as a "phenomenology of conjure" $(1992,154)$; a constellation of images that reveal the workings of the spirit that verges on what Gates introduced as sign. The product of such reasoning is a literature that is authentic in terms of its representation of blackness; in that it acknowledges the spirit of blackness and celebrates its humanity rather than being sidelined in some psychopathology of racial pathos. Moreover, such literature opens a forum of discussion that creates a connective vision of how black literature started and how it progressed from rage and militancy toward liberation. The vision of this novel literature is not constricted by any paradigm but is rather enlarged in the sense of establishing and defining the contours of social edicts.

Dove's "phenomenology of conjure" is not confined by any category of racial orientation. Dove writes as a writer does, not necessarily black, or woman, black and woman registers do feature in her 
work but they certainly do not control it. Versatile in exploring the reaches of her identity, Dove has sailed the turbulent waters of racial identification of self, but never at any point in time had she drawn on it as the sole definition of self. Despite the fact that her work is highly acclaimed by many scholars and critics, there were critical moments in her career that point out that her work is not fully grasped by many critics regarding the issue of racial representation. Critics like Arnold Rampersad did not spare her the discomfort of sharing his vitriolic comments on the "meagerness" of her racial register. However, Rampersad has softened his view when he reflected on the universality of Dove's work that "instead of an obsession with the theme of race, one finds an eagerness, perhaps even an anxiety, to transcend- if not actually to repudiate- black cultural nationalism in the name of a more inclusive sensibility (Rampersad 53). He advances his argument when he refers to Dove's literary product as one that maintains a "disciplined" distance that "prizes objectivity" (53). He adds that she writes of black experience "mainly in the course of ordinary things- where a given human situation is recognizably black but not defined even in part by the tension that many of us see as ever present between the races" (Rampersad 55). Malin Pereira, to mention another example, refers to Dove's treatment of race as a cause of discomfort for her readers mainly as she points out Dove's stance vis a vis the Black Arts Movement, an issue that the paper will come back to later:

One of the most important elements of Dove's work, and a source of the discomfort, concerns her treatment of the role of race in shaping her- and our identities. Dove's self fashioned identity, both personal and poetic, challenges the black essentialism of the Black Arts Movement of the 1980 and 1990s. Although Dove knows that a strategic essentialism identifying attributes supposedly core to black identity and culture has helped ensure the survival of African Americans in a racist society, she clearly recognizes the limitations on such notions (1).

Although there is cosmopolitanism in the title of Pereira's book Rita Dove's Cosmopolitanism, Pereira has taken the universality out of 
Dove's work and instead added an expectation that it should fit a generic form of blackness that she does not even care to define. Catering to the taste of the majority that will never be satiated was never Dove's vocation. Instead, going out on tangents has been a better forte for her.

Dove staged numerous attempts of an entry into blackness across her literary career manipulating different registers in order to find the "best way in" (Vendler 1995 A, 160). Helen Vendler argues that "Dove's skin color gave her blackness" (1995 B, xii) "as a donne" (1995 B, 61) but has never prescribed a limit on what she could be. Vendler most succinctly sums up Dove's virtuosity in terms of a discovery that "blackness need not be one's central subject, but equally need not be omitted" (1995 B, 82). Vendler elaborates on the "daunting task" that Dove has undertaken in her being "faithful to, and yet unconstrained by, the presence- always already given in Black American- of blackness" (1995 B, 87). Despite Dove's loyalty to her racial orientation, she rises to the occasion of expanding beyond the threshold of her skin color and soar to the limitless expanse of humanity at large. Hers is a poetry that flows from a place of literary and spiritual abundance that eludes the grip of social or racial circumstance.

In more than one context, blackness to Dove has always conditioned a return to history that grounds it in facticity as it journeys toward the reaches of the fictitious. In her seminal book Understanding Rita Dove, Pat Righelato notes that Dove "has negotiated her artistic space with grace and determination" (1) that helped bring African American history into the mainstream of American poetry (4). The allure of history also attests to giving Dove as Vendler suggests "a prefabricated plot, and the lyric has had to dance to its tune (1995 B 66). Her engagement with history helped universalize her work. In Sonata Mulattica, Dove formulates a consciousness that impacts the potential shaping of the history of world music and of contemporary black cosmopolitan life.

With reference to Black essentialism that Malin Pereira reflected on earlier, Therese Steffen argues for a margin of safety that Dove elects for in order to guard against the evils of limitation: 
In moving from the historically informed political occasion to the most beautiful imagery, she ties herself to a sense of urgency yet at the same time keeps a safe distance from the limited and limiting essentialism of the black aesthetics. Hence Dove opposes, even fights tyranny both in a broader and more subtle way (8).

There are moments in her work in which she rightfully chooses to move out of the black predicament only to come back to it by creating associations with other universal groups of the disadvantaged world wide, like what she did in 'Parsley' in her volume Museum in which she inhabited the mind of a Dominican dictator who ordered the massacre of a field full of Haitians for their failure to pronounce the letter " $r$ " in parsley. Dove confesses to Therese Steffen that the notion of black art is so confusing:

The concept is not pure: the insistence on black art is just a device, a way of establishing territory or generating publicity. It was necessary at one time to underscore that otherness in order to get any kind of respect whatsoever, but the insistence on difference also requires one to erect certain walls or obey certain rules - all of which is anathema to the artist. When I was growing up, I did not think in terms of black art or white art, or any kind of art. I just wanted to be a writer (169).

Knowledgeable of her role as a writer, Dove shares her gratitude to earlier generations who had to muddy their hands in fighting for a definitive black aesthetic with Particia Kirkpatrick:

Sometimes I feel like getting down on my knees and saying thank you because these battles have been already fought. And these are not easy battles between confessionalism and beat poetry and formalism, or whether poetry adheres to gender or not, or whether it adheres to whatever black aesthetics. These discussions have been on the table. We haven't had to clear the path first before writing (37). 
She insists in her interview with Johnson and Peaboby that the 'pendulum had to swing back' (6) from the reference to only blackness to a wider range of consciousness. She later defines what a black artist is and what a black artist does: "A black artist is defined by differences more than rules--- so we can more a bit more freely in the field. We have surmounted what Langston Hughes called the "Racial Mountain" (Steffen 170). Dove's testimonial liberates her from all constraints that punctuated the work of her predecessors. Blackness figures in Dove's work in the form of helpless poverty, social diminishment and human trauma. Blackness is communicated through her eyes and that of the other, at moments emerging like an anathema or a deformity of self that spells doom on the gazer rather than on the gazed upon. Dove has always created a community of characters who through their plurality of vision have presented definition of what blackness is. Dove's work shares with the readers a revised universalism that makes her a citizen of the world.

II.

Written in the form of a sonata in five movements, Sonata Mulattica is Rita Dove's tribute to the worlds of poetry and music combined. A poetic prodigy herself, Dove orchestrates a piece that races to the apex of her literary repertoire as she merges her poetic terseness and literary thrift that are signs of perfected manner, her authentic characterization, her story teller's instinct and historical weavings of a tale all in one fabric. What emerges is a rhapsody that sings the story of a man who was written out of history partly for his folly or for his fate or for both. The volume presents the ravishing tale of the rise and fall from grace of a violinist who lived his fifteen minutes of fame but died in the shadows. "A footnote in musical history becomes the keystone to Rita Dove's latest book-length lyric narrative" as the International Literary Quarterly characterizes the volume. Paula Woods refers to the eclecticism of the volume as "a much more ambitious effort, using multiple distinctive voices and perspectives to chronicle the complex tale "of light and shadow, /what we hear and the silence that follows." Dove shares the cosmopolitanism of the volume with Charles Rowell in that it is "played out on a bigger stage: it crosses continents and languages and cultures and art forms" (Rowell 706). 
Born a prodigy to a white Polish German mother and an AfroCaribbean father dubbed 'the dark prince,' George Augustus Bridgetower attested to a musical genius unparalleled by the virtuosos of his time. A musical prodigy, he earned the full attention of Ludwig Van Beethoven who dedicated a Sonata to him that they both premiered publicly in Vienna on May 24, 1803 at the Augarten Theatre, Beethoven on the piano and Bridgetower on violin to wide acclaim of musical audiences then. Bridgetower, having no time to practice the sonata, sight read it and improvised it as he went along. The Sonata was entitled "Sonata mulattica composta per il mulatto Brischdauer [Bridgetower], gran pazzo e compositore mulattico" (Mulatto Sonata composed for the mulatto Brischdauer, big wild mulatto composer) Owing to an unfortunate incident in which Bridgetower showed interest in a girl who won Beethoven's affection, Beethoven rededicated his impossible Sonata to the French violinist Rudolphe Kreutzer who deemed the sonata unplayable bringing an end to Bridgetower's fame. The volume records a chronicle of personal catastrophe that engages the fates of composer and performer as they vie against their potential undoing; Bridgetower against receding into oblivion and Beethoven against incapacitation by deafness.

Sonata number 9 opus 47 in A major, named The Bridgetower, is Beethoven's edifice of dramatized grace and gusto morphed in 3 movements that chariot both piano and violin to the unchartered territories of the musical impossible. Knowing that Bridgetower was in Vienna, Beethoven interrupted his work on the third symphony in order to compose a sonata that was later titled the Bridgetower for his lunatic mulatto friend and musical prodigy Bridgetower. Beethoven's Kreutzer sonata, originally titled The Bridgetower narrates a story of struggle. At once playful, intense with all the twists and turns that represent musical excess, the sonata was composed in an act of defiance to challenge Beethoven's prospective fate of deafness. It is at once graceful, playful, conflicted and circular always going back to an initial point of start. The sonata opens with a slow introduction of four bars in A major but suddenly shifts to A minor in a darker version of harmony. A sense of unrest is engendered as the piece careens between major and minor keys, between, anger, anguish and a questionable form of release toward the 
end as the piece closes in an anguished coda. There are hardly any instances of comfort or balance as both piano and violin alternate at playing belabored roles full of twists and turns that build up a sense of surprise with every dramatic rise into crescendos and every anguished fall into diminuendos. Requiring careful musical coordination, the Sonata presented the task of an elaborate conversation in the form of an ingenious call and response between piano and violin punctuated by a cavalcade of extravagant flights into musical madness that towered both Beethoven's ingenuity and Bridgetower's virtuosity. In this sonata as much as in the volume, Beethoven and Bridgetower's fates have intersected in an instance in which Bridgetower tried to work his way up the ladder of musical acclaim while Beethoven attempted to fight against musical extinction represented in losing his hearing. Instead of extending a hand of mentorship to Bridgetower, Beethoven, in the wake of a brawl over an anonymous girl, decided to end a thriving friendship with a lunatic mulatto. Aloneness coupled by a sense of lingering dimishment bracketed Bridgetower's tale after the rededication of the sonata. The driven quality of the Sonata and volume is represented in Bridgetower's struggle to write his name in the annals of history and that of Beethoven's to excel his repertoire in a moment of uncertainty. The tragic sweep of a sonata attests that the impossible is only possible; a sonata the bears the mark of distinction is frozen in time and so is its player whose life is reclined to the shadows of forgetfulness for no credible reason.

It was cheer fascination with Bridgetower's life that ignited Dove's imagination to start the sequence; a task that she for long dodged until it was necessary to see it to consummation: "When I stumbled upon George Bridgetower, I started looking into his story simply because I was fascinated by the astounding fact of his existence" (Brown). The buried tension of a life lived with the potential of greatness that was suddenly snuffed out was another reason that attracted Dove to the story. The need for closure or resolution of such a conflict led her on (Rowell 702). Intrigued by Immortal Beloved, a movie chronicling the life of the greatest musical prodigal of all times, Ludwig Van Beethoven, Dove questioned the presence of a dark young man in Beethoven's entourage. An avid researcher and a capable assembler, Dove managed to piece 
together Bridgetower's tale over the span of five years, attempting to locate bits at a time from reading diaries from Mrs. Charlotte Papendiek, Assistant Keeper of the Wardrobe and Reader to her Majesty Queen Charlotte who was a servant of George III, and whose husband Christopher Papendiek helped to arrange concerts for Bridgetower. Dove's interest in her emerges from her objective take on how Bridgetower was received by the crowds at the time. Moreover, she has also checked the Sally Hemings Diaries in order to look into the possibility of whether Thomas Jefferson attended one of Bridgetower's performances in Paris, a speculation that was later confirmed by the diaries, however, Dove intentionally relegates Jefferson to a footnote in the book. Dove characterizes her process of discovery "like tracking the coordinates of some meteor," "OOh, he went there; he appeared here," mapping the trajectory of his life. Other than that, he was a blank slate" (Manser). However, Dove features a dexterous ability to not only assemble but also to reconstitute shrapnel of thoughts into a mosaic that in the words of Robert McDowell "jar our lazy assumptions" (61).

In an interview conducted in New York, Dove defines the scope of this book as a story not just "of his life but about the nature of fame, the nature of memory, public memory. Into the mix we pour the story of this mulatto boy. It's also a story about youth. Youth is exotic, as well as race" (Lee). However, race is a topic she touches upon with decorum and grace as she frames Bridgetower's ordeal as one of the color line. She presents his story as that of the banished prince of the past whose reinstatement is celebrated in a carnival of music. Deemed a "historical novel" by the New Yorker, the volume defines history as the backdrop against which Dove tells her tale. In her dedication to the book, Dove attests to the historical authenticity of the content of the volume "although this book is a work of literature, any resemblance to actual people, events or locales is deliberate" (14). There is no doubt that Dove's knowledge of literature emerges from a dedication to the historical (Wallace 12). Dove elaborates on her search for "that moment where a historical event intersects with an ordinary person's daily trot" (Smith 28). It is not the grand arc of history that Dove is seeking but mostly the underside of history, those little, vanquished nobodies in the course of history (Rubin 
10) whose story was left out for political or cultural reasons. History to Dove is made up of "moments rather than times. A series of sketches instead of frescoes, it is always discontinuous" (Khyar 356). It cannot be featured on a strip of film but rather a surprise finding that ensures a lucid sense of mobility that is not "static, stitched in place like the pages of a high school history textbook; nothing about it placidly objective, dependable and real. Dove envisions history as motion in itself, something like the stars, constantly in flux, always coming toward or receding from those of us who inhabit the evanescent present" (Stein 108).

Part of Dove's fascination with the tale of Sonata Mulattica is mostly ascribed in one's sense of selection of what to include and what to exclude as one manages to storify: "I've always been intrigued by the way history works, the way we decide what is mentioned" (Lee). Dove refers to her take on the historical in Sonata Mulattica in an interview with Charles Rowell:

I knew I didn't want it to be a straightforward narrative; I wanted it to be as fractured, in a way, as the sputtering of that brief moment in history when George Bridgetower's star flared up and then went down. I wanted to convey the sensation of how history had buried him. The only way to do that was to not make the story simple and straightforward, but to show the many different factors that influenced his life, and how much of not only his life but of the lives which touched his we'll never know at all----And so it dawns on us that history itself is a fiction. We think of history as a narrative, but all we have are little flashes, like Morse code; we connect the dots into the narrative line we call History. So there I was, trying to keep this whole book up in the air as I wrote it. I found it counterproductive to even think about it in the kind of terms one would use to answer the question: "What's it about?" I could have said, "If I tell you his story, that's not what it's about at all (696). 
The undependability of historical accounts is what motivates Dove to jazz the volume up with "figments of the author's imagination" (14) thus making space for poetic license or what she refers to as the "poetic crucible" (14) in which "amalgams of truth and fantasy" are transmuted. Dove refers to the history that is included in the volume as another history:

When I began work on Sonata Mulattica, I didn't approach the story of George Bridgetower from the outside. I didn't think: What an interesting historical character; let's see if I can give him flesh! No, I wanted to get to know him personally; and though I began researching like a historian, I soon began searching for details that would help me imagine what it would be like to walk the streets of London in 1790 as a little dark-skinned boy with a violin tucked under his arm. The end effect may appear to be a personalization of the grand historical narrative, but the very nature of poetry is to confound the notion that you can stand back and look at what's happening; with poetry, you are put deep in the thick of things (Hanna and Basosi).

Delving into the life and the emotive environment of Bridgetower sets this work apart as the work of the historian since Dove manages to not only fictionalize events but also fabricate the feel and the details of a life that went unrecorded. Envisioning a possibility of what he was like is an act of a dramatized humanization of a story that needed to be told.

Dove's poetic sequence, however, tip toes on the tight terrain of fact and fiction with an equal poise producing a text that is a trade off between the factual and the imaginative or rather imagination compelled by fact. The volume recreates a universe powered by a single fact, the unfortunate fate of Bridgetower, and impeccably embroidered by the fictitious rendering of threads of narrative detail that are devised to humanize both Beethoven and Bridgetower as dramatization of their plight ensues and to flesh the bare bones of the obscure legacy of Bridgetower whose name was crossed out of musical inscription of history. It is in this spirit of the multiplicity of historical perspective that 
Sonata Mulattica is formulated. As for the narrative bent in the volume, Dove has insistently functionalized narrative in the service of her lyric poetry. She tells William Walsh that she likes "the term "lyric narrative" because that's the kind of melding I try to do. Again, it comes back to genres, to different forms. I see no reason why a narrative can't have strong lyric qualities and what a lyric cannot have the narrative's sense of time running through it. That combination has been very fruitful for me; I enjoy mixing" (148). She elaborates on her ability to "approach narrative in away that did not merely tell a story from beginning to end" (Walsh 150) but rather operated on a "starburst fashion" by virtue of which all the bits and pieces fall in place.

The task that Sonata Mulattica consummates is to present "a feel" rather than the fact about Bridgetower's life by conjuring up a social milieu represented in myriad characters, some of them public, some of them just imagined riff-raff. Dove's quest is to put flesh on the bare bones of Bridgetower's life, a child prodigy whose "home was music, his home was his violin. He was exotic, he was good-looking, he was well spoken, but I think somewhere inside he was very alone" (Lee). The volume attempts to piece together a mosaic of life that was broken up by race selectivity and caprice. The possibilities of what would have been had he been wiser or had his fire not have been snuffed is another issue that Dove takes up with fervor. Had an African prince or a liberated slave rose to world acclaim, a change of musical world history could have made itself manifest. In stead, the volume taunts a cautionary tale of Bridgetower's disappearance from the annals of history.

The volume has a driven quality featured in a prologue, five movements and a short play presenting the tragic sweep of Bridgetower's life. About her choice of movements rather than sections, Dove shares her vision with Charles Rowell:

I did not want people to think of the sections in the traditional way of poetry books, as if each of them is selfcontained and representing a step in Bridgetower's life. I wanted to use "movements" in the musical sense, inviting the reader to proceed not poem by poem, step by step through a 
section, but rather to allow each "movement" to build, to swell around you while retaining the reverberations of the movement before. That's one of the reasons why I decided on movements, besides reflecting on the sonata concept----So you're getting "a life" in a poetic cycle bundled with "a short play," whose humor is, to say the least, coarse. And every once in a while the poet steps into the circus ring to play the clown, do a few somersaults, but as comical as those performances might be, in the end they cannot avert tragic fate (700).

Moreover, Dove makes the best use of an orchestrated effort of voices, sounds and characters that never stop to fascinate. Quite masterful of dramatic detail, Dove presents a theatre of characters and voices that participate in the creation of his dramatic saga. Characters include King George and his son, court lady Charlotte Papendiek, the writer of the diaries, Papa Haydn Bridgetower's mentor, Emperor Napoleon, concert impresario Johann Salomon and street fiddler Black Billy Waters. True to life to its most minute detail, Dove's choice of characters expands beyond key historical figures to include simple people on grassroots level. Of her choice of characters, Dove seems to be comfortable to elect for a volume that features men and only women in the background, a comment that Vendler made about her earlier work (1995 B 64). There are instances in which the poems play duets of voices that reflect not only facts but also temperamental engagements. Dove gives voice to the voiceless to tell in words what chords and musical measures stopped short of narrating. Building up to a crescendo of signification, diction is meticulously chosen as a touchstone to characters and the veracity of their tales. Dove adds flesh to the bare bones of characters like Beethoven as she skillfully delineates a unique character sketch of the composer, wild and uncanny and full of caprice himself. The volume changes voices as though it represents an impossible feat of orchestrated entities. Characters pop up as they populate the world of the volume only to fade away in the background of the pathos in which Beethoven and Bridgetower emerge as main players. 
Music is the tour de force that heals the breach of racial injustice as it manages to equate black and white in the metaphor of the piano that is closely associated with Beethoven's virtuosity. In the context of the volume, the white European prodigy shared moments of his glory with Bridgetower in a musical dialogue that dictated their equity of status as talented performers. Music has always been Dove's language of the sacred. She confesses in her interview with Smith that "my musical bent has spilled over into my writing. I love to experiment with the motion of words, to me, language that doesn't sing in some way isn't valid" (32). Pat Righelato makes a similar comment when she refers to music as "the keynote of her poetry" (4). In an interview with Camille Dungy, Dove builds the bridge that interlaces the musical with the poetic: "I've always been intensely musical, and my poems have often reflected that musical impulse. First of all, let me say it straight out: I believe that if a poem doesn't sing, it has no business being a poem" (1028). It is noteworthy to mention that Dove has taken up music very early in her career when she played the cello and then the Viola de Gamba. She has also taken voice lessons. Her fascination with the classics and with blues and jazz helped her embrace a similar cadence in her poetry. Not only does she talk about music, but she is also influenced by the way in which ideas are conceived at the heart linguistic sound. Sound is her portal of entry into meaning; a situation in which the poem is perceived first hand as a "cascade of syllables" (Hanna and Basosi) acquiring meaning. Dove tells Charles Walsh about the process of writing music into the work:

There were moments while writing when I felt like an organist, sitting at this massive instrument with a hundred things going on at the same time: working the foot pedals, pulling the stops to bring in the trumpets, then the stringsthere would be a moment when I'd think: "Ah, finally, my understanding of classical music is paying off!" (698).

In this volume, Dove presents music as a metaphor of transcendence of race and its limiting refigurations. But has music made the victor out of Bridgetower? Dove responds with great uncertainty toward the end of the volume when she maintains distance from Bridgetower and his tragedy. Dove successfully locates African American 
musical motifs, like call and response, in Beethoven's Sonata as a testimony on the inspiration that Bridgetower endowed Beethoven as an African. Like the sonata, the volume features poems that reflect on the communicability of voices, characters and strips of narrative that thrive in the cosmos of the book.

The poetic sequence narrative drama features a preface in which Dove involves her reader in the process of the writing of the volume. The text is fragmented and it is the reader's task to rearrange the poetic mania presented in it. The volume probably mirrors Bridgetower's mental process as he careens between the extremes of fame and infamy featuring a spectrum of insanity and mental chatter. "The Bridgetower" prologues the volume as it narrates the gory details of a cautionary tale of a prince who ended up banished from the table of privilege. The poem builds an aura of a lamentable if-ness about "what could have been" that would reverse Bridgetower's doomed fall from grace. The poem presents a cacophony of clauses that exudes the exceptional talent of Bridgetower juxtaposed against the unutterable fated defeat that Dove deliberately delays. The poem presents a deluge of information that is at best disconnected which in turn mimics the numerous crescendos of the sonata only to culminate in the mystery of unknowing. The reader is not meant to fathom the depth of disaster, alternatively the reader is only led along to a finish line that is not yet defined, one that is only intimated:

If $\mathrm{was}$ at the Beginning. If

he had been older, if he hadn't been

dark, brown eyes ablaze

in that remarkable face;

if he had not been so gifted, so young

a genius with no time to grow up;

if he hadn't grown up, undistinguished,

to an obscure old age.

If the piece had actually been,

as Kreutzer exclaimed, unplayable - even after

our man had played it, and for years,

no one else was able to follow-

so that the composer's fury would have raged 
for naught, and wagging tongues

could keep alive the original dedication

from the title page he shredded. (19)

A dark genius "with no time to grow" cautions the reader of a murky future and of an amputated glory. Playing the impossible Sonata that Kreutzer deemed unplayable, Bridgetower had no parallel in the world of performance. Dove elaborates on his virtuosity in order to hold in check the anticlimax of the rededication of the musical piece in "Kreutzer's" name, another musical virtuoso who deemed it unplayable. Minimalism instills a sense of mystery as it informs the poetic thought of this text as she maintains poetic distance from the act of "shredding" that becomes Bridgetower's life and fate for the years to come. Dove builds the bricks of the tragedy but first she deplores Beethoven's vulgar manners and his commonplace upbringing, his deafness and his failed endeavors to find true love as culprit behind the tragedy that she has not yet named.

She then moves to tell the joyous part of the tale of victory as she refers to the intimate relationship that grew between Beethoven and Bridgetower who interrupted composing the third symphony in order to write a sonata for his "lunatic mulatto" friend who after a glorious performance "leapt up from the piano to embrace his lunatic mulatto" (20). "Who knows what would have followed?" is a question that Dove asks most deploringly to initiate Bridgetower's fall from grace into the pit of historical oblivion. The two rock stars' friendship, as Dove proclaims, becomes as impossible as the Sonata itself because of a fight over a girl that won Beethoven's affection. A girl robed in obscurity seals the doom of Bridgetower whose music could have made it into the record books but instead ended up being a dream that could have empowered young blacks to transform their matchbox violins to oases of chances that could have rendered the impossible tangible enough. Only if. Bridgetower as Dove proclaims did play the impossible; "Beethoven's Sonata no 9 in A major, op. 47, also known as The Bridgetower. Dove's terseness is at its best in this text, as she carefully and meticulously hands out detail about the story in fragmented bits of poetic shrapnel parodying the wrenching tale of a virtuoso wiped out of a world of musical possibilities. She holds till 
the very end the surprise that connects all the disparate facts; what emerges is a selected sense of conscious awareness of the tragedy not only of Bridgetower but also of his race.

Prologue of the Rambling Sort defines the paradoxical tendencies of the book as a "tale of light and shadow/ what we hear and the silence that follows." The sense of reversal of fate is highly dramatized in light and dark in sound and silence that represent the abruptness of fate that transformed the possibility of Bridgetower's glory into a paltry tale of diminished proportion. Dove defines the volume unmistakably as a story:

This is a story

About music and what it does to those

Who make it, whom it enslaves--- yes

Slavery of all kinds enters into the mix (21)

Dove clearly makes recourse to the cumbersome historical baggage of the times represented in slavery and the unspeakable horrors that it visits upon the reader's expectations represented in human degradation, dehumanization, mutilation and the like. However, the slavery presented here verges more on the artistic; a representation of enchantment that holds one captive, to a tale, to a rhythm and to a thought. A specter from the past rears its head as Dove proclaims "all kinds" of slavery have room in her mix. Slavery in this context anticipates an undesired visitation of racial issues. It announces a form of mental limitation that enslaves one to an idea that breathes doom. Moreover, Dove uses slavery as a descriptor of one of the most liberating of moments, the instance of creation of a tune or of the playing of it. The slavery of skin color as a parallel universe of awareness that chains is introduced in the volume but is later kept sotto voce.

Movement one entitled The Prodigy presents the twists and turns of the story of birth and life of Bridgetower orchestrated through the myriad voices that speak out the story. The narrative register shifts with every poem as a new awareness of Bridgetower is born. Dove's narrative bent seeks expression in her selection of crude prose. Capriccio charts a vision of Lieutenant Field Marshall, a decorated and well practiced musician who brought Bridgetower into the life of royalty; a gypsy 
mulatto crowned to a life of delicacy and artistry. In the course of the poem, Dove refers to Bridgetower as:

$$
\begin{aligned}
& \text { an array of Nature's eccentricities- } \\
& \text { a dwarf, an African, perhaps a gypsy } \\
& \text { or ferocious Turk or flat- faced Borneo, } \\
& \text { summoning each before him } \\
& \text { dressed in the deep blue and red livery } \\
& \text { of the house of Esterhazy } \\
& \text { to see who among them would bear } \\
& \text { with the most decorum } \\
& \text { the imperial trappings (31) }
\end{aligned}
$$

In favor of leaving out the reference to race, Dove makes constant recourse to Bridgetower's physical description as a "rough head," (31) a cavalcade of impossible curls that houses the delicacies of music that "Master Haydn" his mentor had to "squeeze [it] out of him" (31). The reference to 'master' complicates the racial register of the poem as it circumscribes Bridgetower's status into slavery especially with the slave trade on the rise during this period. However, Dove contrapuntally refers to him in Recollection Preempted as "a musical Prince" who garnered the attention of the crème of the musical crop including Haydn who mentored him and composed for him.

Recollection Preempted conjures up the infantile voice going through the "rough head" for the first time in the volume. Bridgetower the child, surrounded by the seriousness of the court, prizes the puppet theatre as his "favorite hiding place."

Dark but glimmering,

A cave inside

A treasure chest.

I sang to myself.

It was like being buried

In jewels (33).

The poem toys with the reference to dark as it transforms it into light, glimmer and the surprise of treasure find. However, death hovers 
over the poem morphed in references to 'cave' and 'buried;' a situation that fortune pales against and fails to neutralize. The poem plays as a monologue inside Bridgetower's head situating him within the safe contours of memory and chronicling his growth into "the stinging embrace" of music that endowed him with a "toy violin" for his relentless listening as a child. The poem shuttles across both ends of the successfailure spectrum portraying him as a "withering prince" who was chased away leaving behind Paris with its revolution and Brighton and Bath. Paris Panting narrates Bridgetower's virtuosity as a child son of a moor, traveling and performing in the European world.

At nine years, the youth astonishes

For his maturity of playing.

We at Le Mercure celebrate his arrival

To the Parisian concert stage (36).

The poem alternates narrators as Dove relegates her role of the storyteller to that of Bridgetower himself singing his own praise in "Praise me. I am small" (36).

What Doesn't Happen opens with a carriage journey through Paris and an excursion in memory of "the drums from the islands in his father's tales" (37). Associations of sound is how the young Bridgetower attempts to put within perspective a life he left behind, shrouded in miasma and emptied out of meaning versus another life that he is striving to build. Dove does not seem to reflect on actual detail in Bridgetower's life prior to his rise from rags to riches. His life and his awareness of it, like his cadences, are "jumbled together/ except the thudding dirge of his heart" (37). Dove builds at will a language of entrapment that breathes enslavement as a haunting doom represented in "the violin case in his lap/ twitch with every jounce, like an animal trapped under the hunter's eye;/ that he can sense down the shrouded alleys, danger rustling just as surely/ as he can feel spring's careless fingers feathering his chest and smell/ April's ferment in the stink of the poor marching toward him" (37). Whether he ends up being the hunter or the hunted, it is for fate to speak its final word. Dove recreates the moment of fear that has overtaken him 
before his first performance at court and the ability of music to qualm his fears:

Nonetheless, he ignores his heart's thudding and steps out onto the flickering stage, deep and treacherous as a lake still frozen at sunset, aglow with reflected light.

Soon the music will take him across; he'll feel each string's ecstasy

thrum in his head and only then dare to open his eyes to gaze past the footlights at the rows of powdered curls (37).

Dove dwells on the detail that highlights Bridgetower's charisma being surrounded by two girls "one a younger composition of snow and embers" and the other "the dark, dark yet warm/ as the violin's nut brown sheen... miraculous creature/ who fastens her solemn black gaze on the boy as if to say/ you are what I am, what I yearn to be" (38). The lines echo an emphatic dream of being shared by blackness and clearly achieved in sublimity and excellence by Bridgetower who like his name suggests towers the expectations of his people. The charismatic Bridgetower, released from the hypnotic hold of music on him can return a woman's gaze.

Windsor rebuilds the saga of the darker brother as banished prince who is advised out of sight "I was told to practice/out of sight in the servants' wing" (39). The lines parody Langston Hughes' "I too Sing America" with the darker brother sent to eat in the kitchen when company comes. Although Bridgetower is reinstated as a crowned musical prince in the realm of the rich and powerful, he cannot be accommodated in the palace in social settings outside of his moments of glory. A dexterous violin player at seven, he emerges as the lucky lad "with a feather in his cap" with "all the world left behind" (40), a world of misery shrouded in the mystery of forgetfulness.

Mrs. Papendiek's Dairy seems to be yet another resource that assists in piecing together the truth behind the musical prodigy. Dove features a number of sequences with the same title offering a straight forward factual rendering of what really happened tinged with the poet's figments of imagination. Mrs. Papendiek's Dairy (1) figures how father 
and son were received in the palace. Father Bridgetower is introduced as "an African/yet a man of discernment and varied tastes,/ exquisite deportment and considerable/ beauty of form" (41). Dove deliberately tosses the word 'yet' in the sentence to reflect on the accepted social norms at the time- Africans are probably deemed not as civilized as this exception. Bridgetower is introduced as a child who "possessed admirable /restraint, and played the Viotti Concerto/ with an eloquence and refinement/ rarely delivered by his more celebrated seniors" (41). She also reflects on the father being well versed in social life: "The Father Bridgetower entertained the table/with his judicious and amusing observations;/ he knows several languages and seems at home/ in the world" (41). Dove manages to rebuild through the diaries an assessment not only of fact about Bridgetower's family by also of feel on what it was like to have been part of such social entourage. Overemphasis on the riches of dress emphasizes Bridgetower's well earned status as the stock of the dark prince of lands beyond cultural knowability.

The Marine Pavilion Brighthelmston reflects on Bridgetower's self as it grows to challenge borders and limitations that are expected of him "you need to imagine yourself larger/than the country you occupy. You need to make/ others understand what you have glimpsed,/ against a morning sky, inside a nutshell" (43). An attempt to reach out through art is made in the poem empowered by an act of seeing the beauty within in a moment of epiphany. Beauty is inside all of us, a love so grand that one gets in touch with by simply listening in on the miracle of being.

People, feast upon this

Miracle- such beauty shining

Almost weightless above

The net strewn encampments of the whelk eaters;

This vision a promise from your king to be:

Proof that each of us hears inside

A ruinous, monumental love (43)

Dove willfully enlarges not only Bridgetower's fellings but also his status as a man of dreams who is capable of translating his greatness beyond prescribed limit. Paradoxical to the intent of The Marine Pavilion 
Brighthelmston, The Wardrobe Lesson builds on stereotypes of Africans as perceived by Europeans: "An African loves color- so let it be/ red for out promenade along the Steyne/ with a splash of yellow/ to inflame their watery sensibilities"(45). In this instance, Dove intentionally exposes the reality of limit set by race selectivity that appreciates no distinction and fails to see the beauty within. The poem affords a cold reality check that presents a comprehensive experience of race from the perspectives of white and black; in that Dove does not approach the text as a black author who celebrates blackness but rather as one of cosmopolitan neutrality.

Mrs. Papendiek's Dairy (2) narrates a misfortune that befell the first event introducing Bridgetower to musical society. The standoff of not being able to find appropriate orchestral accompaniment by the royal musicians who refused to play that night for the dismissal of their appeal to be allowed employment off royal payroll left Mr. Papendiek with one solution to host the concert at their house. Dove presents fashion details to the utmost meticulous precision in order to help delineate the feel of the place that hosted Bridgetower's first performance of the Viotti Concerto "who sparkled with pathos" (47). Mrs. Papendiek exclaims that "others were as deeply affected/ at the prospect of such talent among us" (47).

The Sea Side Concerts, features in elaborate prose, George Bridgetower as "a phenomenal musical talent" who "aged only ten, the youth astonished all with his maturity of rendition and technical perfection" attracting some 550 attendees who were "left enthralled by the experience" (49). A pupil of Haydn and the grandson of an African prince, Bridgetower manifested "lofty bearing and eloquent expression" that made a musical marvel out of him (49); a reality that Dove presents as transcendence over his racial bearings. Bridgetower's color suddenly becomes transparent, no one sees it, except for only his exoticism and exceptional talent unmatched. The audiences could only hear and witness a musical prodigy in the making. Dove dwells on music as a metaphor of traverse and a tour de force that heals that breach of racial injustice and its limiting refigurations as it manages to equate black and white represented in the metaphor of the piano. But the question remains, has music made the victor out of Bridgetower? Or was it just a streak of success that was shortly terminated? 
Disappearance emphasizes Bridgetower's slight and simple being, a boy accompanied by his instrument of fame. The poem traces movement in "the boy lifts his arm" or "the violin floats up to kiss his chin" (50) as it vividly displays the interconnectedness of child and instrument in an act of intimacy that exudes creativity and innovation. $\mathrm{He}$ is not only the target of musical acclaim but also of women's passion. However, Dove chooses invisibility for him outside of his musical world:

But a boy looks out

From the backs of his eyes

A boy stays where you put him,

Invisible, until you hiccup-

(Full floods, on my mark: Go!)

And suddenly he's there. (51)

Part two Bread \&Butter, Turbans \& Chinoiserie presents a lyrical section that starts with a quote from Samuel Johnson that Dove elects for as a commentary on the Bridgetower family move away from London to Vienna that reads like a pronouncement of doom; an augur of death into a life that is attempting to start: "When a man is tired of London, he is tired of life, for there is in London all that life can afford" (53).

Black Pearl (59) is burdened with racial register as Dove embroiders her words carefully and most intently with "nigger" and "chain" in "Pathological hit of the day: nigger on a golden chain;" a statement that defies the expectable. Dove's utterance, most dramatically warped, reflects on a contrapuntal engagement between 'gold' representing glitter and value and "nigger" standing for opaque darkness that does not take into account Bridgetower's fame. The mention of the chain dramatizes the enslavement and sense of entrapment that Bridgetower the prodigy cannot for all his ingenuity escape. In rewriting a long history of atrocities done unto blacks, Dove inters declarative names long forgotten like "the African valet," "the maidservant black" and the tabooed "nigger" that build a theater of cruelty in acknowledgement of a tumultuous history not yet set to rest. Degradation and servitude are monumentalized in the poem's diction. Such history is set against Bridgetower's success story to deflate it and render it waste, 
the same way it has discounted the lives of African Americans across a spectrum of time.

Concert at Hanover Square features the voice of Bridgetower and a friend of his sharing their story with the world. The "we" in the poem is rather curious as it builds Bridgetower into a community of blackness morphing its own anger and discontent at the world that is responsible for its sense of anguish.

Do not think for a moment

That we were boys. Souls

In a like anguish, perhaps;

Or when in a fortunate instant

We forgot ourselves- gray mice

Biting each others' tails,

Rolling in the grass in our woolen knickers,

We did not understand how to covet.

We knew hatred

Because we smell it

All around us, it sang in the cool glasses

Tinkling over our heads,

The carefully tended laughter,

The curious glint

of a window appraisal (63).

The first two stanzas reflect on Bridgetower's social life away from his talent. Hatred and "want" were life's bequeath along with perpetual anguish. Yet music has a magic of transformation that spins a heritage of hardship and of arbitrary cruelty into a rhapsody of release that builds up the banished boy of a world past into the victor. Music becomes a right of passage that leads him from nothing into something grand:

I was nothing if not everything

When the music was in me.

I could be fierce, I could shred

The heads off flowers for breakfast 
With my bare teeth, simply because I deserved such loveliness (63).

Music emerges as a raison d'etre that weaves a tapestry that merges ambition with hatred and envy that typify both the speaker and Bridgetower. Bridgetower's testimonial of entitlement to love well earned is in itself his acknowledgement of self and acceptance of his struggle. Dove amplifies Bridgetower's voice as a man in charge of his fate; a moment in which slavery and subordination have no role to play. Music emerges as transcendence from a world of inequity.

Black Billy Waters, at His Pitch chants a beautifully playful villanelle that bites off the issue of racial inequality with a smile:

All men are beggars, white or black.

Some worship gold, some peddle brass

My only house is on my back (67).

Dove maximizes the benefit of the chance rhyme in "black" and "back," as she goes beyond blackness as a place that kept tally of whip lashes to a place that houses the dream of a home carried around on one's back representing a state of burdensome homelessness. Beggary is a condition of lack akin to body and soul that keeps blacks and whites engaged. The poem is endowed with an unmistakable tragic sweep caused by the ritual repetition of the line that ticks like a bomb reminding the world of the wrong done unto blacks. Dove gives voice to Haydn, Bridgetower's teacher in Hayden Overheard as she fictionalizes her way to merge the voices of pupil and mentor:

It is a sad thing always

To be a slave

But if slave I must, better

The oboe's clarion tyranny

Than a man's cruel whims (69).

Reference to slavery makes recourse to Bridgetower's status and the oboe to his color and its sadness of sound. Although music maintains the power of liberation, Haydn fails to glimpse the hope of break from the doom that has befallen his student. 
Mrs. Papendiek's Diary (3) spins myriad strands of narrative around the life of Bridgetower and the joy that attended his musical events and the sense of completeness that they bestowed upon the attendees. Mrs. Papendiek retorts: "we had declared the Bridgetower concert to be/ our winter party and so were free of social obligations" (71). The Dressing reveals the mysterious world of Bridgetower's father's life as he reflects on his nothingness, an idea that recalls Concert on Hanover Square. The poem features the father's voice as he denies his own sense of manhood.

Outside, I am not a man

I am a thing

Which in fine company

Arouses awe:

That curious fusion of fear and longing

I have learned to make use of (63).

Instead of calling for appreciation, he arouses the curiosity of a crowd being a thing representing the world of the exotic. He names fear and longing as a motivating power that ensures his survival. The excessive exoticization of race overtakes this stanza as the father establishes beyond a doubt the curiosity that he is taken for. In his face can be seen "all the hopes of its enslavers" (72). Dove discusses the exoticism of the Bridgetowers in an interview with Charles Rowell:

$\mathrm{He}$ is quite aware that many people do not see him as himself, but rather as the reflection of their prejudices. And if he can't get others to see him as he really is, then he can at least manipulate their preconceptions to his advantage. "If you can't be free, be a mystery"-I'm quoting myself! — but it's pretty wily advice. In effect, he's telling his son: "I can't get them to see me as a man, so I've learned to reinforce their fantasies through outlandish clothing; in this costume I'm free to act out their superstitions. I'm not only granted immunity but can extract a little fun and even profit from it." Father Bridgetower is our self-styled African Prince; at the same time, he is sad about this situation. Again, a touch of 
tragedy. Of course, he uses the same tactics when promoting his son: when he discovers the boy's musical talent, he pushes him as a prodigy but also dresses him like a young African prince - which undoubtedly helped the pair to get ahead in a society where romantic notions of exoticism were never far removed from cruelty. It's not that different from what the Janissary bands did (702).

In The Dressing, Dove intensifies the reference to enchainment represented in enslavers that have probably discounted his presence and his son's into paltry existence. He elaborates on the inability of others to understand him:

Here on this Isle, I am

A continent, I am so large

They cannot grasp my meaning.

I am the Dark Interior,

That other, mysterious and lost; (72)

Away from the gaze of the crowd and contrary to the sense of dimishment that Dove built in the first section of the poem, the protagonist realizes his own adequate being as a person ungraspable in terms of virtues and values but an ignorant otherness to whom he rests in mystery. The poem echoes Langston Hughes' "I am the Darker Brother" only that Dove's basks in more mystery that draws on regal lineage that crowns Bridgetower as a prince:

This is their system; they understand

The service I provide- no trifling pleasure.

And if to them I am no more

Than a mere phantasm,

A swarthy figment of their guilt,

Yet I came to these shores yoked

To my name: Bridgetower, a reach

And a stretch- and now

I would give up my small empire

To you, my son, but not ever 
Must you forget that you are indeed,

A Prince- just not the pitiable one

They worship here, not just the one

They can see (73).

Bridgetower the father admonishes people's stereotypical representations of his son as "phantasm," rather he is a prince to a world they have no access to. The Undressing features a moment of transformation in the life of Bridgetower in which he was "to become a proper British/gentleman: cuffed and buckled/ with breeches and a fine cravat" (73). The poem also presents a monologue in which Bridgewater questions his personal worth. His references to himself are heavily laden with wastefulness and ending in "smudge," "a quenched wick, a twig shrouded in a snow" (80) as though the poem chronicles the nakedness of his soul.

Section three starts with The Petition, a poem that presents justification for what was left unsaid. Whether Dove is trying to make sense of Bridgetower's petition for survival sent to the world or of his ingenuity is left to the reader to arbitrate. Bridgetower is a man to whom the world made time "Because there comes a time/ Because there was time" (101). His ardent drive to make a difference in the world is recorded in "Because I want to be known as a gentleman/ everywhere" (101). His success is also ascribed to Haydn's mentorship that "saved me" (101). Bridgetower's voice soars in the world of the poem as he claims a place amidst the world of the great. The title of the poem however echoes the tone of subjection that might have colored Bridgetower's mental chatter being fully aware of an opportunity that does not manifest itself to people of his stature.

To the Continent chronicles Bridgetower's dreams and wants as he crosses from childhood to adolescence. His music was too immense to be made space for in the world: "the world was not as large as the sound/ I sent to it" (102). Yet an urgent need for love emerges "Then I wanted love, whole sheets of it/to wrap myself warm for sleeping" (102). The poem outlines Bridgetower's search for female companionship "to find love that resists, notes that will not fit; /I want to be appalled \& staggered 
in equal measures, I want blood and blood's aftermath" (102). The poem reads like a supplication that spells Bridgetower's doom. His excessive need for love that emerges from a place of want is the reason that encouraged him to cross the line with Beethoven's companion leading to his downfall.

First Contact records Bridgetower's comments on the first encounter with Beethoven, a man whose wild disposition brackets their relationship short: "I hear he's a wild man, a proletarian/ who forgets to shave and rejects tutelage" (109). His greatness, however, is unparalleled "but at the keyboard a wonder" (109). The reader hears not as much Bridgetower's voice as that of Dove in bitter diatribe where Beethoven is concerned. Ridicule, however, shifts from Beethoven to Bridgetower, a man whom the party plans to "play," this "ugly flushed little man/ everyone calls the Moor" (110). The poem establishes beyond a doubt Bridgetower's social degradation in preparation for his undoing.

Polgreen, Sight Reading establishes an unspoken hiatus between Bridgetower and Beethoven as the poem elaborates on Bridgetower's stream of consciousness as he performs the impossible sonata. The poem opens with an elaboration on the difficulty involved in performing the sonata. Dove reflects on Bridgetower's mastery as a performer and also as a visionary who spies the walls of anguish that punctuate Beethoven's life. Suspension is pleasurable "that delicate fulcrum between crash and sheer evaporation, a dissipating breeze" (113). Dove's language in this context is premonitory in that it passes the verdict of demise on Bridgetower evaporating into nothingness. Bridgetower proclaims:

He frightens me. I've never heard music

like this man's, this sobbing in the midst of triumphal chords, such ambrosial anguish, jigs danced on simmering coal.

oh, I can play it well enough-hell, I've been destined to travel these impossible switchbacks, it's as if I am skating on his heart, blood tracks 
looping everywhere, incarnadine

dips and curves

I am not making sense. (114).

Bridgetower's success from Dove's perspective is owed to his dexterous ability to feel his way through the feelings and thoughts of a man who was seemingly enigmatic to him at first, but to the reader's surprise, Bridgetower has successfully penetrated him and could learn about the workings of both his mind and heart.

The Performer defines Bridgetower's place in the world of musical fame. Stepping out is an act of exteriority that takes Bridgetower's consciousness outside of his interiority of self and into "silence" an inexpressive space in which language fails and music flourishes.

I step out.

I step out into silence.

I step out to take

My place; my place is silence

Before I lift the bow and draw

A fingerwidth of ache upon the air.

This is what it is like

To be a flame: furious

But without weight, breeze

Sharpening into wind, a bright gust That will blind, flatten all of you- (119).

Dove's extravagant repetition of "step out," "my place" and "silence" reflects on Bridgetower's aching process of getting to grips with his own reality. His is a music that emerges from a place of ache; a flamed anger that has music for an only vent. Silence frames his experience and limits his outreach to the world. Dove insists on placing Bridgetower in a vacuum that transcribes him as a man of color rendering fury the only channel of expression for him. The poem introduces snippets from Brigetower's memory that reflect the struggle between him and Beethoven "the master" over "Wien" an empress followed by 
Bridgetower's apology "My apologies-/ I only meant that she is --magnificent" (121). The poems' finale echoes Bridgetower's cry for recognition as a human "if this world could stop/ for a moment/ and see me" (121). The yearning to be seen and to belong to a community diagnosis Bridgetower's outcast status and his inability to perceive of his being. A search for self and a celebration of such a self is in order.

If I could step out

Into the street and become

One of them,

One of anything,

I would sing-

No weep right here - to simply

Be and be and be---(121).

Volkstheater: A Short play for the Common Man entitled Georgie Porgie or "A Moor in Vienna" satirizes the rift between both Bridgetower and Beethoven as it stretches from seriousness to the comic. Following the artistic fashion of the times, Dove included this farce as a way to humorize the event as though dragging the whole issue into bathos. Drawing upon farce, Dove introduces a section in the volume that capitalizes on exaggeration, extravagance, absurdity and improbability. Dove develops the farce after farces in Vienna at the time with a caste of characters with Bridgetower, Beethoven, Schuppanzigh, director of Augarten concerts, Ferdinand Ries, Beethoven's copyist and Tussi a barmaid. A chorus of bad girls featuring drunken clientele at the bar and general riff raff punctuate the air of delirium that the farce conjures up. Dove intelligently functionalizes the farce to slow down the time of the volume, dramatize the central event and humorize it out of existence using tart language and finally to keep the reader entertained with the eclecticism of form and genre that she employs at will (Wriston). Dove places this farce at the center of the book because it is probably the literary piece that pulls all the weight of change in that one simple social event could change the course of one's life. Exaggerated as the farce is, Bridgetower's change of fate is synonymous with the form skillfully depicted by Dove. 
In one instance, Schuppanzigh talks to Beethoven about Bridgetower proclaiming: "I see you brought along your shadow" (126) and later jokes in a drunken stupor "a man and his shadow (127). Dove insists on picking up such a reference to the shadow again as a reminder that Bridgetower's existence depended so much on Beethoven and otherwise would not have been able to build his edifice of fame without him. Shadow is certainly a racial designation that becomes Bridgetower best as he spirals his way down into obscurity. Jokes about his inability to understand or speak English exacerbate his status into a diminution that does not take into account his ingenuity. Although Dove capitalizes on the moment in which Bridgetower is verbally bullied in order to give him a voice of self confident retort: "oh! but I can! My mother is half polish, half German; and my real father spoke seven languages, English, German, French, Hungarian, Arabic" (128). Dubbed the moor by Schuppanzigh, Bridgetower outspokenly responds "But I am a natural man, born under a magical caul," (134) a reference to himself that falls into bathos:

I'm that last plump raisin in the cereal bowl;

I'm the gravy you lick from your mashed potatoes'

I am creamier than chocolate, juicer than ripe tomatoes!

I'm older than the ages, yet younger than a minute; (134)

Dove shifts from the lightheartedness and intended humor to a darker part of the play in which the chorus of bad girls seemed to have found interest with Bridgetower. A conversation between Bridgetower and a barmaid takes place in which he let her in on a secret:

A Black man's kiss is a dangerous item

and must be handled prudently.

now that kiss there will hold its potency

for a good little while. for about a week,

I wager, you can place that little palm of yours

anywhere on your person and feel

my lips there- or

you could sample the whole article tonight.

what time do you get off work? 
A decision is made. Seven is the time for both of them to meet. The whole issue gets way out of proportion as Beethoven joins in with his fateful comment: "Womanhood is not to be treated like --- trash!!/ This is an abomination! You are an abomination" (137). Although Bridgetower quickly interjected "We're just having a little fun" (137), Beethoven refers to Bridgetower as a "heathen" and a "savage" thus drawing on the classical stereotype of the Negro Savage. Dove takes poetic license in fabricating the tale as Beethoven most ruefully retorts:

She was a goddess, a Queen,

And would've fled this rude scene

if she'd only been given a chance.

such pale hair and green eyes!-

what a suitable prize

for a German dead- set on romance.

I have written about her

in my moonlight Sonata-

though her name was another's, who cares?

upon crossing God portal

true love turns immortal,

transformed into heavenly airs! (139).

The play winds its path down uncharted territories in which the fate of the barmaid intertwines with that of Beethoven's beloved, a woman of noble upbringing who rejected him in marriage in favor of another man. It seems, as Dove suggests, that the issue gets out of hand because of Beethoven's jealousy aroused by Bridgetower's appeal to women in general. The farce closes on Beethoven's determination to teach Bridgetower a lesson and make him "taste the high price"/ of my affection" (139). The decision to rededicate the Sonata to "A barn yard mule!!" (139) has already been sealed.

The fourth movement All is Ashes brackets a life of possibility rendered waste as it plays out a dirge announcing death in the title "All is Ashes." Beethoven's rededication of the Sonata to Kreutzer has placed a tomb stone on Bridgetower's dream transforming his fortune from the son of an African Prince to the prodigal with no bearings and moorings. 
Esterhaza, Prodigal starts with "What remains? (146) a rhetorical question that has dropped its verb parodying Bridgetower giving up his dream of musical fame. The world of "sheer phantasmagoria" of "mystery's faint perfume" writes its own epitaph calling for the need to take cover. Bridgetower reminiscences instances from childhood in which taking cover was a pleasurable moment.

The puppet theatre was my favorite

hiding place, dark and glimmering,

a cave inside

a treasure chest. I sang to myself.

It was like being buried in jewels (146).

Dove's choice of diction especially of puppet theatre draws upon Bridgetower's inability to decide on his own fate. He emerges like a puppet in the hands of the rich and powerful only capable of fashioning his own death "buried in jewels" leading to "silence where once there were ceaseless/ operas" (147).

Eroica gives full vent to Beethoven's caprice, a genius who "squandered the world's utterance" (151). The poem chronicles the dynamic relationship of communicability between Beethoven and Bridgetower, a relationship that Bridgetower commented upon earlier in First Contact:

So that I could read his playing, see my score

Transcribed on the air, on the breeze- I breathed

His soul through my fingers and gave up

Trying to listen; I watched him and felt

The music- it was better than listening,

It was the last pure sound...(151)

Dove would have liked to have the reader think that Bridgetower was not only ears to Beethoven but also soul and inspiration. Regret ensues coupled with the aggressive reference to him as a savage thus reinforcing racial register on the one hand and outlining Beethoven's loss of hearing and loss of the sense of direction: 
Why did that savage say it? Why did I hear

What he said, why did I mind what I heard?

Good days, bad days, screech and whistle:

Sometimes I lay my head on the piano

To feel the wood breathing, the ivory sigh (151)

Loss is intensified in the poetic cosm in a double take; Beethoven's loss of a friend transcriber of sound and Bridgetower's loss of an opportunity of musical brilliance.

Movement five Nomadia announces Bridgetower's nomadic existence and his brush with the issue of race. "Moor with Emeralds" announces a future of service for Bridgetower in which he learnt to be at the beck and call in "I am here to serve. I await/ a word- any word!" (176). A stark reference to the color line dramatizes the seemingly light attitude that the poem propounds in a Bridgetower monologue in minor cadence:

You may think me a mere charcoal coolie,

Yet I bear such beautiful redundance!

I am its jubilant Negro

For I have

been waiting all my Life to step into

this Moment, your Moment, arms full (177).

A subservient creature, Bridgetower emerges as "your most/ humble/ obedient/ exuberant/ servant" (177) who is willing to live some else's moment of glory rather than his own. Dove capitalizes on 'Life' and 'Moment' in an ironic instance satirizing a dimishment of Bridgetower's life in order to accommodate a Moment that is not his own, a moment that eventually led to his undoing.

Nomadia fashions Bridgetower's leave-taking of a life and a dream that he willed into existence by his musical ingenuity. The poem adopts a biblical tone in the first line, "In Search of pasture, a place to lie down in" (189) that reflects a moment of distress that Bridgetower lives, a 
detour in life he has to take back into "his mother's breast," and back to "the land of his fathers" (189). This land is one wrapped up in a mystery and a miasma of vision since "my father never mentioned" it.

Fatherland, mothertongue.

I live, speak

Elsewhere. This island. (189)

The poem outlines a difficult itinerary that took Bridgetower all over the countries of Europe in search for himself or what Dove calls "the multiplying selves/ caught in the mirror lined rooms" (190). En route is a condition of inbetweenness that is at once dangerously sweet a situation in which pain is willed into yearning for a self in the making:

Air, breathe me in. Take this thick

Heartache, this wily, gelatinous yearning

And make me everywhere

A nothingness.

I will be

without boundaries, then;

an infestation of humors, invisible companion:

ageless like a child.

No one will be able to avoid me (191).

In this part of the poem, Bridgetower sings his own saga of heartache modulating into an instance of accepted annihilation. Nothingness is what has become of him as he wills himself into a surreal existence that resists limit and thrives outside of constricted boundaries that the world had set for him. He emerges a child, intact and full of ingenuity that challenges aging as he regenerates himself into an existence that "no one will be able to avoid" (191). London, the last section of the poem opens with rumination and a question: "What am I looking for?" The question reflects tedium and loss of vision:

I am tired of my eyes, I am tired of my ears,

My fingers itch for music but I am tired of

hearing it. 
The need to enter into the world of emotions and desire presents itself as an alternative to a sense of the beautiful never explored in his life "why not taste/ then or touch----/ the cool slide of a marble hip" (193). A sense of frozen pleasure most ironically presents itself in the poem as an alternative to the palpable joy that music presents to him; a joy now paradoxically perceived as a tedious task that he cannot totally fulfill in a moment of jouissance.

Self Eulogy (195) passes a final verdict of vacant emptiness that colors Bridgetower's life at the moment of departure and entrance into a new existence:

Finally the verdict's

Come through.

All the pots licked

For their stew

Lie empty, cold;

Soon the last copper coin will arrive---

But, dear Papa- I've

Tasted the gold (195).

Dove's mention of copper and gold chronicles the change of fortune that Bridgetower has experienced, only that tasting gold is an experience that is quite unforgettable. In the Witness (197), Dove adds a different spin on the racial register of the volume as she refers to Bridgetower as "half blood" and mulatto "I couldn't help brushing my sleeve/after greeting- afraid he'd sprinkle some of that brown my way" (197). Dove persistently uses the past tense in her reference to a past that is irrecoverable in "so he was a fiddler/ something of a stunner of his day" (197).

The Composer's Coda voices the dreams of Beethoven as he morphs his own requiem of regret for the end of those dreams:

I wanted fame. I wanted love.

I deserved bliss, but bliss

Scares easily (203). 
Beethoven's moment of flickering fame does not detract from his sense of self worth. A deliberate sense of deservedness punctuates the poem. Fame, love and bliss should have been attendants to a life of ingenuity. Vienna though perceived as a "grave lilt" was the locale in which Beethoven learnt to value "the static," a value that juxtaposes the explorative journeying of his earlier days. A transformation of all things spontaneous and beautiful into constrictive frameworks "Fame became moot/ Love a strategy" limited his chances at success culminating in a rude awakening:

Now I know none of this is real,

None of this exists.

That next moment,

Shimming before you? (203)

In this instance, Dove skillfully dictates doom on both Beethoven and Bridgetower. Their doom is most interestingly intertwined. Capitalizing on the terseness of haiku, "Instrumental" summarizes in minimalist strokes the rise and demise of a musical virtuoso.

A stick

A string

A bow.

The twang

As the arrow

Leaves it. (207)

Dove's deliberate omission of the violin propagates an absence that equates Bridgetower's retreat from the world of fame. All what is left of him is a "stick," a string and a bow; the useless remnants of a career that could have taken off to the skies of glory. The bow is transformed from being a musical bow capable of unparalleled ingenuity to a cross bow only trained in the art of destruction; a fate that Bridgetower had to fulfill because of a reckless moment of folly. What remains is:

the breach

no one sees

shivering

struck (207) 
Failure is the only bequeath of a man who could have had it all. Instead of the rise to glory, Bridgetower was dealt a blow that ended his dream and his fame.

The End, with Mapquest aids Dove in writing her way out of Bridgetower's ordeal as she manages to define her relationship with him. Dove's quest for direction culminates in the question:

Will I cry for your Polgreen? Will I drag out your end

Though it is long past, though I drove slowly past

The place of your dying days and recorded

What I knew I'd find there-

I tried to focus on the thought of you

Laid out in one of those miserable cottages

Do I care enough, George Augustus Bridgetower,

To miss you? I don't even know if I really like you.

I don't know if your playing is truly gorgeous

Or if it was just you, the sheer miracle of all

That darkness swaying close enough to touch,

palm tree and Sambo and glistening tiger

running circles into golden oil. Ah,

Master B, little great man, tell me:

How does a shadow shine? (208)

Dove maintains her aesthetic distance from Bridgetower as she scuttles his streak of glory gone awry. All through the volume Dove has dexterously sketched the most elaborate life for Bridgetower, a life that took account of not only who he was but also how he felt as a mixed race prodigy in Europe at the time. She has, indeed, made a heroic entrance into his world, an act which was partly motivated by curiosity and shame. Dove admits to the urgency of getting deeper into Bridgetower's life in her interview with Hanna and Basosi: "In a way, I was ashamed: as a classical musician and an African-American, I felt that I should have known about him." Dove focuses on the fact that Bridgetower was not only a prodigy but he was also a novelty that managed to make the best use of his talent that at once liberated and imprisoned him. While the 
volume does not celebrate the return of a reinstated prince, there were moments of victory that the poetry recorded. But his victory has a very short streak. Sally Michael Hanna asks Dove about her intentional disengagement from her haunting fascination with Bridgetower represented in the last poem in the sequence. Dove's answer magnifies the safety margin she keeps by way of objectifying his person:

One of the biggest problems with trying to inhabit a color blind society - "blind" is a perfect word for it! - is that identity cannot be reduced so simply. Everything about humanity is complicated, and that is a good thing. Just because there's this mixed race violinist who disappears from history - just because the prodigy turns out to be half African - doesn't necessarily mean that he was a wonderful human being; oppression does not automatically make him a hero. I kept running up against the uncomfortable suspicion that he was a chauvinist as well. Of course, everybody was a chauvinist back then; it was a man's world, after all. The poems of Sonata Mulattica are overwhelmingly male oriented - I think there are only three women who speak in the entire book - because that was the world he moved through. Hence my admission in the last poem: "I don't even know if I really like you." I felt I had finally gotten close enough to him to say. "Hey, I don't know if we would been friends." That, to me, was a moment of freedom: I had gotten past the labels - look, a great musician, a mixed race prodigy! - to see him a flawed human being. Could we have even talked? (Hanna and Basosi).

The moment that Dove refers to is one of confrontation with Bridgetower and with herself. Although she has created Bridgetower from oblivion by putting flesh on the bare bones of the snippets of fact in her research, she finally realizes that she is standing face to face with a mere stranger- a character whose inflections, fears and joys have kept her poetic world busy but one that maintains a real life dimension that ought to be scuttled, the same way his fame was snuffed out early. Disengaging from him is Dove's attempt toward demythologizing him refusing to put a 
racial label on him. He is not necessarily the hero who has entered into the life of grace and riches but one who ended up expelled from it. To her, he might have been a lovable person or not but one fact remains that he is a "miracle of all that darkness" who successfully, even for a short period of time, made "a shadow shine.".

In order for gauge Dove's development as an author in Sonata Mulattica, one needs to reflect on the representation of race as a cardinal notion in her earlier work. Dove's early steps as a writer were taken with extreme caution in terms of the representation of blackness. The Yellow House on the Corner, her first volume, remotely chronicled themes of slavery with an objectivity that isolated her from achieving a right of passage. Most of the slave narratives were told with the voice turned down. Museum, her second volume, represents a better anchoring into the world of blackness, only that Dove manages to universalize it out of the African American condition and present it as a form of freakishness that calls for the wonder of the gazer by historicizing about the underprivileged of the world. Thomas and Beulah, her third and Pulitzer prize winning volume, spins the tale of her grandparents from their youth to their death thus engaging history as the back drop of the book. The volume presents better grounding for Dove in the representation of blackness by having her two protagonists be black. Entry into the world of blackness was made, however, in Grace Notes, a volume that celebrated her personal acceptance of the color line with an acute awareness of the sense of confinement that it incurs. On the Bus with Rosa Parks, repays a debt of gratitude to Rosa Parks who galvanized American's Civil Rights Movement. The volume reserves the fifth section to Rosa Parks a woman whose inaction has called for drastic change in the history of African Americans and of America at large. Dove insists on grounding her in a social milieu that authenticates her existence and that of blacks at the time. Minimalism decodes the interesting poetry of the disarticulated. Functionalizing silences is Dove's stock in trade when she is trying to heighten the dramatics of the tacit.

Sonata Mulattica marks Dove's apogee of professionalism in that Dove managed to unearth a treasure trove of history that went untold. Instead of being held captive in its thrall, Dove devices means by which 
she could break loose from its grip and instead work with it as a malleable substance of memory. Dove's attempt is one that managed to storify history in "a more inclusive sensibility," if I may draw upon Rampersad's statement. Sonata Mulattica is a deliberate departure from the world of disarticulated silences, from the barriers of limit on language and from the curtailment of the told. An entry into a lyric narrative without limit is what affords Sonata Mulattica the virtue of traversable space not only to Black Americans but to blacks world wide. Crossing literary genres is in itself a testimony that to Dove's artistry there is no limit. The volume is a tribute to world music and race. The story that one reads engages the interest not only of white or black but also of an entire cosm of artists and musicians. In Sonata Mulattica, Dove opts for liberation from the limit that language posits, she traverses terrain that was not traveled before seeking the enclosure of history of the world. Her foray is one that challenges the limitation in the perceptual and emotive apparatus of writing that daunted her earlier.

The volume answers Gates' and Baker's dream of art that writes about race but is not denigrated by it, of literature that shapes the consciousness of blackness but is not influenced by the ruthless gazer. Dove's sensitivity toward a literature that reconstitutes a new black subjectivity has empowered her to seek history as a way to salvage a past from oblivion and to transcend it in favor of a wider range of consciousness that does not take racial rage into account. The volume presents a reflection on a life in its wholesomeness along with a comprehensive exposition of a social milieu that afforded racial commentary from the sides of white and black alike. Dove successfully neutralizes the color of the text as she scuttles both composer and performer. Dove creates art that brings back the glories of the Harlem Renaissance that Langston Hughes argued about in "The Negro Artist and the Racial Mountain:"

We younger negro artists who create now intend to express our individual dark skinned selves without fear or shame. If people are pleased we are glad. If they are not, it doesn't matter. We know we are beautiful. And ugly too---- If colored people are pleased we are glad. If they are not, their 
displeasure doesn't matter either. We build our temples for tomorrow, strong as we know how, and we stand on top of the mountain free within ourselves (30).

Dove's artistry is one of crossing the cosmopolitan expanse of race. Although Bridgetower does not get to share in the table of brotherhood, Dove is welcomed to the table of literary victory. Cosmopolitanism of feeling is an experience that best describes a writer of Dove's versatility. Surmounting Langston Hughes' racial mountain seeks a final crowning in Sonata Mulattica. Dove indeed writes as a writer does.

i ''Saturation' in Black poetry I mean several things, but chiefly (a) the communication of Blackness in a given situation and (b) a sense of fidelity to the observed and intuited truth of Black experience. I postulate this concept as a third category for evaluating black poetry. As in the other two, theme and structure, this category only exists in relationship to the entire work and is employed merely to deal with an aspect of poetry that warrants discussion and appreciation. In other words, just as it is misleading to speak of theme to the exclusion of structure, and vice versa, it is difficult if not impossible, to speak honestly about saturation without considering the other two. In addition, one must not consider the poem in isolation but rather in relationship to the reader/ audience, and the reader to the wider context of the phenomenon which we call, for the sake of convenience, the Black Experience. (104) Saturation may thus be seen as a perception, a quality and a condition of theme and structure" (Henderson, Progress Report on a Theory of Black Poetry: 1975, 104).

\section{Works Cited:}

Baker, Houston A. "Rita Dove. Grace Notes." Black American Literature Forum, 1990. 24.3: 574-77.

---. "There is No More Beautiful Way: Theory and The Poetics of AfroAmerican Women's Writing." Afro-American Literary Study in The 1990's. Houston A. Baker Jr. and Patricia Redmond eds. Chicago: University of Chicago Press, 1992 A. 135-163.

---. "Generational Shifts and The Recent Criticism of Afro-American Literature." African American Literary Theory: A Reader. New York: New York University Press, 2000 A. 179- 217. 
---. "On the Criticism of Black American Literature," African American Literary Theory: A Reader. New York: New York University Press, 2000 B. 113-131.

Brown, Jericho. "Until the Fulcrum Tips: A Conversation with Rita Dove." Dec

2011.http://blog.bestamericanpoetry.com/the best american poetry/2011/12/unt il-the-fulcrum-tips-a-conversation-with-rita-dove-and-jericho-brown.html. Retrieved Feb, 2014.

Dove, Rita. Sonata Mulattica: A Life in Five Movements and a Short Play. New York: WW .Norton and Company, 2009.

Dungy, Camille T. "Interview with Rita Dove." Callaloo 28.4 (2005) $1027-1040$.

Hanna, Sally Michael and Duccio Basosi.. "Interview with Rita Dove," Incroci Di Civilta, Venice, Italy. April 7, 2014. https://www.youtube.com/watch?v=nYBpRgUBKG8. Retrieved, August 13, 2014.

Harris, Reginald. "Viennese Idol: A Review of Rita Dove's Sonata Mulattica." May 25th, 2009 http://www.postnoills.com/main/?p=113. Retrieved Feb 2014.

Henderson, Stephen. "Saturation: Progress Report on a Theory of Black Poetry," African American Literary Theory: A Reader. New York: New York University Press, 2000. 102-112.

Hughes, Langston. "The Negro Artist and the Racial Mountain," African American Literary Theory: A Reader. With Winston Napier, ed. New York: New York University Press, 2000. 27-30.

Gates, Henry Louis. "Canon Formation, Literary History and AfroAmerican Tradition: From the Seen to the Told," in Afro-American Literary Study in The 1990's. Houston A. Baker Jr. and Patricia Redmond eds. Chicago: University of Chicago Press, 1992 A. 14-39.

---. Loose Canons: Notes on the Cultural Wars. New York: Oxford University Press, 1992 B.

---. Black Literature and Black Theory. New York: Methuen, 1984. 
---. "Preface to Blackness: Text and Pretext," African American Literary Theory: A Reader. With Winston Napier, ed. New York: New York University Press, 2000. 147-164.

Johnsen, Gretchen, and Richard Peabody (1985). "A Cage of Sound: Interview with Rita Dove." Gargoyle 27: 2-13.

Kirkpatrick, Patricia. "The Throne of the Blues: An interview with Rita Dove." Hungry Mind Review 1995. 35: 36-37.

April

Lee, Felicia R. Poet's Muse: A Footnote to Beethoven. New York Times.

http://www.nytimes.com/2009/04/03/books/03dove.html?pagewanted=all.

Retrieved Feb 12014.

Manser, Ann. Rita Dove: "Renowned Poet Tells UD Audience Story Behind Recent Book." 30 April 2013. www.cas.udel.edu/news/Pages/ Ritadove-reading.aspx. Retrieved Feb 1, 2014.

McDowell, Robert. "The Assembling Vision of Rita Dove." Callaloo, No 26 (Winter, 1986) pp. 61,2.

Pereira, Malin. Rita Dove's Cosmopolitanism. Chicago: University of Illinois Press, 2003.

Rampersad, Arnold. “The Poems of Rita Dove.” Callaloo Winter 1986. 9.1: 52-60.

Righelato, Pat. Understanding Rita Dove. South Carolina: University of South Carolina Press, 2006.

Rowell, Charles Henry. "Interview with Rita Dove." Callaloo 31.3 (2008). 695-706.

Rubin, Stan Sanvel and Earl G. Ingersoll. "A Conversation with Rita Dove." Black American Literature Forum Poetry Issue (Autumn 1986) 20. 3.: 227-240.

Smith, Stephanie Izarek, "An Interview with Rita Dove." Poets and Writers Magazine, 22:2 (1994:Mar./Apr.) p.28

Steffen, Therese. Crossing Color: Transcultural Space and Place in Rita Dove's Poetry, Fiction and Drama. New York: Oxford University Press, 2001. 
---, Therese. "In Conversation with Rita Dove." Crossing Color: Transcultural Space and Place in Rita Dove's Poetry, Fiction and Drama. New York: Oxford University Press, 2001. 167- 177

Stein, Kevin. "Lives in Motion." Private Poets Worldly Acts: Public and Private History in Contemporary American Poetry. Athens: Ohio University Press, 1996. 108-126.

Taleb-Khyar, Mohamed. "An Interview with Maryse Conde and Rita Dove.” Callaloo (Spring 1991)14 .2: 347- 366.

Vendler Helen. Soul Says: On Recent Poetry. Cambridge: Harvard University Press, 1995 A.

----. "Rita Dove: Identity Markers," The Given and The Made: Strategies for Poetic Redefinition. Massachusetts: Harvard University Press, 1995 B. 61-88.

---. "Introduction," The Made: Strategies for Poetic Redefinition. Massachusetts: Harvard University Press, 1995 B. ix-xii.

Wallace, Patricia. "Divided Loyalties: Literal and Literary in the Poetry of Lorna Dee Cervantes, Cathy Song and Rita Dove." Melus. Vol. 18, No. 3 (Autumn, 1993), pp. 3-19.

Walsh, William. "Isn't Reality Magic? An Interview with Rita Dove." The Kenyon Review (Summer 1994) 16: 89-101.

Woods, Paula. 'Sonata Mulattica: Poems' by Rita Dove. Los Angeles Times. May 17, 2009. Latimes.com.. Retrieved Feb 1, 2014.

Wriston, Jillian. Sonata Mulattica: Rita Dove's Juggling Act. http://www.poetsquarterly.com/2013/07/sonata-mulattica-rita-doves-jugglingact.html, Retrieved Feb 1, 2014.

The New Yorker. Sonata Mulattica. August 2, 2009. http://www.newyorker.com/arts/reviews/brieflynoted/2009/04/27/090427crbn brieflynoted1. Retrieved Feb 2014 
